\title{
LATARJET PROCEDURE ON ANTERIOR SHOULDER INSTABILITY IN PROFESSIONAL SOCCER PLAYERS
}

\author{
CIRURGIA DE LATARJET NA INSTABILIDADE ANTERIOR DO \\ OMBRO EM JOGADORES PROFISSIONAIS DE FUTEBOL
}

\author{
Guilherme augusto Stirma ${ }^{1}$ (i), Ewerton Borges de Souza Lima ${ }^{1}$ (i), Deginaldo Holanda Chaves ${ }^{1}$ (i), \\ Paulo Santoro Belangero ${ }^{1}$ (i), Carlos Vicente andreoli ${ }^{1}$ (i), Benno EJNisman ${ }^{1}$ (i) \\ 1. Universidade Federal de São Paulo, Paulista Medical School, São Paulo, SP, Brazil.
}

\section{ABSTRACT}

Anterior glenohumeral instability is a frequent cause of professional soccer players' removal, reduced performance, and prolonged recovery. Players are subjected to intense physical contact and high performance, thus demanding lower rates of recurrence after surgical correction so they can return to sport quickly. Objective: To assess professional soccer players treated by the Lartajet technique considering the rate and time of return to sports activities, complications or failures. Methods: Analysis held between 2010 and 2018 of professional soccer players diagnosed with anterior shoulder instability operated by the open procedure of Lartajet in our service. Results: The mean return to professional sports was 93.5 days. The mean time of surgery in relation to the first dislocation was 12.4 months. Each athlete had 4.3 shoulder dislocations until the procedure was performed. The rate of recurrence was zero and subluxation was not observed. Conclusion: The Latarjet procedure allowed all professional athletes to return to competitive activities quickly, without dislocations and subluxation, negative seizure and without complications during follow-up. Level of evidence IV, Case series.

Keywords: Anterior Shoulder Instability. Soccer. Shoulder Dislocation.

\section{RESUMO}

A instabilidade glenoumeral anterior é uma frequente causa de afastamento dos jogadores de futebol profissional, redução do desempenho e recuperação prolongada. Os jogadores são submetidos ao contato físico intenso e ao alto desempenho, sendo assim necessário atingir menores taxas de recidiva após a correção cirúrgica e retorno ao esporte de forma mais rápida. Objetivo: Avaliar jogadores de futebol profissionais tratados pela técnica de Lartajet com análise da taxa e tempo de retorno às atividades esportivas, complicações ou falhas. Métodos: Análise entre 2010 a 2018 de dez jogadores de futebol que estão atuando em clubes profissionais, diagnosticados por instabilidade anterior do ombro operados pelo procedimento aberto de Lartajet em nosso serviço. Resultados: A média de retorno ao esporte profissional foi de 93,5 dias. A média de tempo da cirurgia em relação ao primeiro episódio de luxação foi de 12,4 meses. Cada atleta teve 4,3 luxações de ombro até o procedimento ser realizado. A taxa de recidivas foi zero e não foi observada subluxação. Conclusão: O procedimento Latarjet propiciou que todos os atletas profissionais de futebol retornassem às atividades competitivas de maneira rápida, sem recidivas das luxações e subluxações e sem complicações durante o acompanhamento realizado. Nível de evidência IV, Séries de casos.

Descritores: Instabilidade Anterior do Ombro. Futebol. Luxação do Ombro.

Citation: Stirma GA, Lima EBS, Chaves DH, Belangero PS, Andreoli CV, Ejnisman B. Latarjet procedure on anterior shoulder instability in professional soccer players. Acta Ortop Bras. [online]. 2020;28(2):84-7. Available from URL: http://www.scielo.br/aob.

\section{INTRODUCTION}

Professional soccer athletes present high risk for traumatic shoulder dislocations. Injuries have become a growing problem recently; the physical demands of the game, the higher speed of athletes and muscle strength are reasons that explain the increase in trauma and its associated energy. ${ }^{1}$ About $2 \%$ of sports injuries in professionals from European teams were linked to the shoulder from 2001 to 2008 , but recent studies have shown a total increase of $3.3 \%$ and from $35 \%$ in the $2006 / 2007$ season to $89 \%$ in $2009 / 2010{ }^{2}$
Anterior glenohumeral instability is a frequent cause of professionals' removal from work, reduced performance and prolonged recovery. ${ }^{3}$ Several techniques have been proposed to restore stability, function and prevent the development of glenohumeral instability, especially when it comes to athletes with high demand and professionals. ${ }^{4}$ The arthroscopic Bankart repair is a therapeutic option with excellent results in non-athletes but higher failure rates in practitioners of professional contact sports athletes. ${ }^{5}$ Thus, the Lartajet procedure is a viable option for arthroscopic repair failure, in bipolar lesions and when there is a high probability of recurrence. ${ }^{6}$

All authors declare no potencial conflict of interest related to this article.

The study was developed at Universidade Federal de São Paulo (UNIFESP), Department of Orthopedics and Traumatology, Sports Traumatology Center (CETE), São Paulo, SP, Brazil. Correspondence: Guilherme Augusto Stirma. Rua Arruda Alvim, 297, Apartamento 205, São Paulo, SP, Brazil, 05410020. guilhermeaugusto89@hotmail.com 
The results of open procedures are higher when compared with the arthroscopic ones in high-risk sports athletes ${ }^{7}$; however, few studies show bone block results related to athletic activity, in this case, soccer. The objective of this study was to assess professional soccer players treated by the Lartajet technique, analyzing the rate and time of return to sports activities, complications or failures.

\section{METHODS}

After a retrospective analysis of medical records between 2010 and 2018, professional soccer players diagnosed and followed by anterior shoulder instability who were operated by Lartajet open procedure were evaluated in our service. All patients signed the free and informed consent form, with the number 09628919.2.0000,5505 of the approval by the ethics committee.

The analysis included sex, age, field position, follow-up time, previous surgical procedure on the same shoulder, number of dislocations, time from the first dislocation to surgery, recurrence, complications and time of return to sport.

Patients with multidirectional instability, reparable and irreparable rotator cuff rupture, SLAP, biceps tendon pathology or acromioclavicular joint involvement requiring surgical intervention were not included. The inclusion criteria were: preoperative positive seizure, bipolar injuries, history of dislocations and professional soccer contract.

The surgical Lartajet technique was chosen because of a lower rate of recurrence comparatively with the arthroscopic one in contact sports athletes ${ }^{8,9}$, patients' profession, bipolar injuries, the surgeon's greater experience and treatment of recurrences by the Bankart repair technique.

The surgery is performed with the patient in a beach chair, access of $6 \mathrm{~cm}$ below the coracoid by the axillary line, identification and removal of the cephalic vein, exposure and osteotomy of the coracoid at its base, preparation of the graft with debridement of soft tissues. Horizontal access through the subscapularis and longitudinal muscle of the capsule joint. The debridement and removal of the anteroinferior labrum is performed. The graft is then fixed to the glenoid with two spongy screws of $3.5 \mathrm{~mm}$, partial thread with washers (Figures 1 and 2). The subscapularis suture is always lateral to the entry of the conjoint tendon to avoid reduction in lateral rotation.

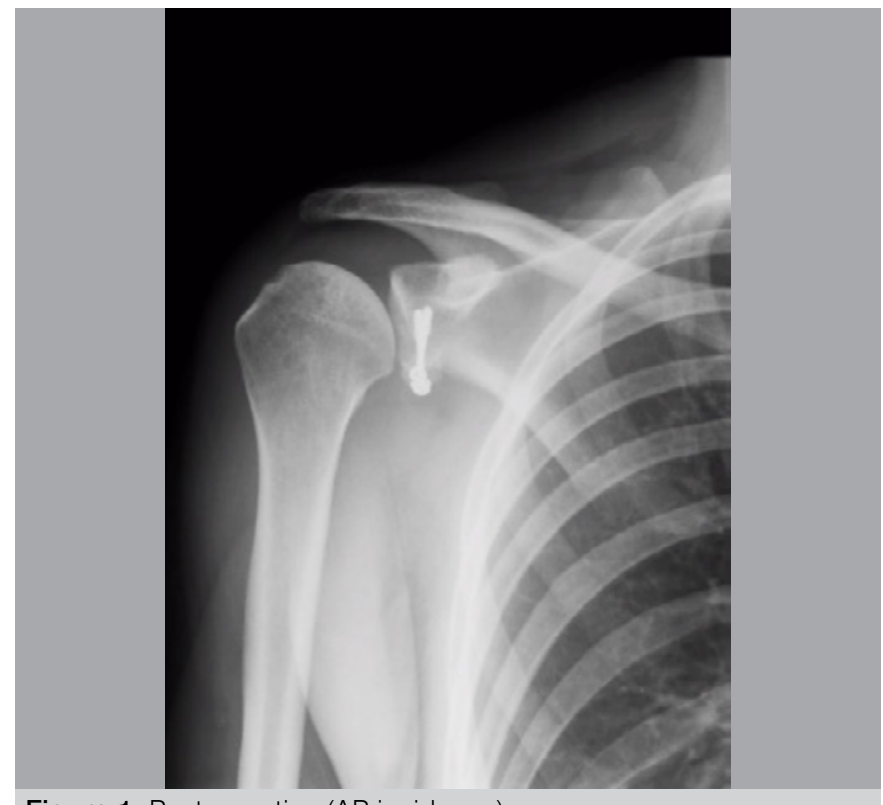

Figure 1. Postoperative (AP incidence)

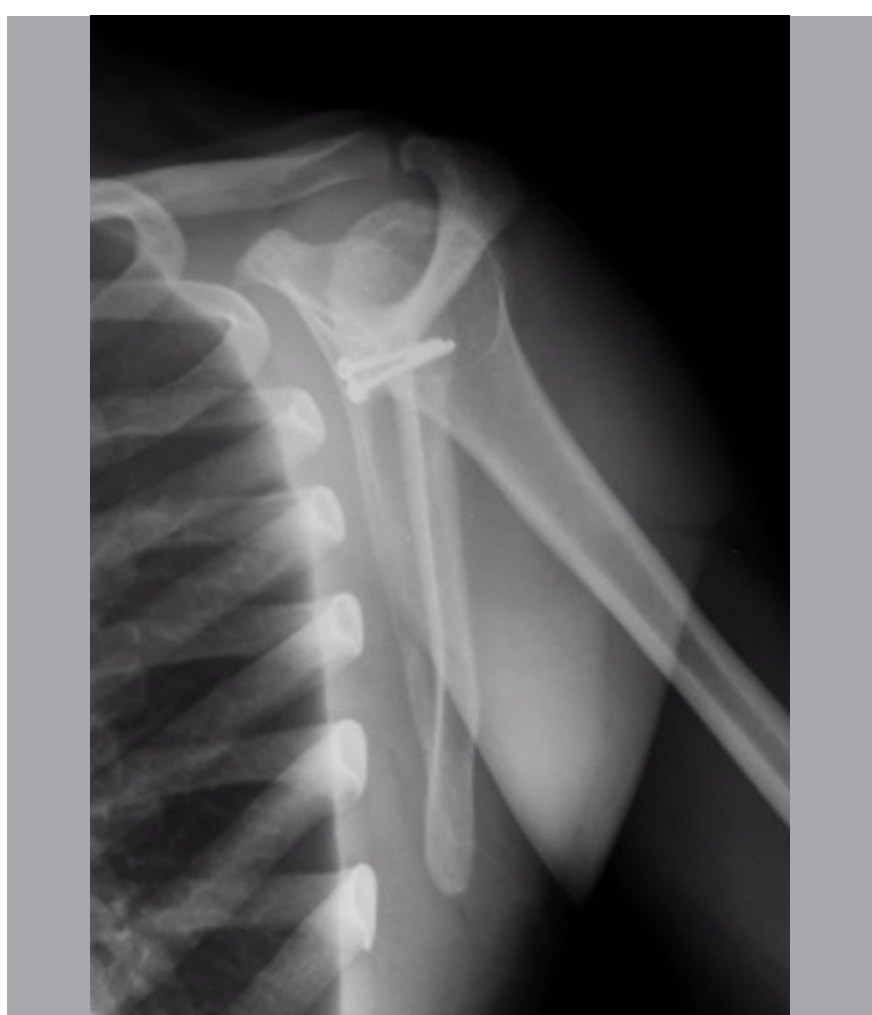

Figure 2. Postoperative (scapular profile).

The patients use sling for two weeks. Physical therapy was performed at the institution, going from passive movements to active movements after one month. They performed Isometric rotator cuff exercises from the fourth to the sixth week and global isotonics from the fourth-sixth week on, as well as the strengthening of the scapula stabilizers, avoiding carrying weights and lateral rotation with $90^{\circ} / 90^{\circ}$ abduction until the eighth week. The evolution is expected to occur from the $4^{\text {th }}$ week up to the $12^{\text {th }}$ week with wide and painless range of motion (ROM). After achieving wide and painless ROM, $V$ strength grade of all intrinsic and extrinsic shoulder muscles, the patient returns to work.

\section{RESULTS}

Ten male professional players with a mean age of 22.9 years (ranging from 16 to 28 years) were observed. In three cases (30\%) the indication of Latarjet surgery was due to failure in arthroscopic treatment (Bankart repair). The mean of return to sports was 93.5 days, ranging from 60 to 120 days. No acute and chronic complications were observed. No case evolved with positive seizure test in the postoperative period.

The rate of recurrence was zero and subluxation was not observed. In relation to the first dislocation, the mean time of surgery was 12.4 months. Each athlete had 4.3 shoulder dislocations until the procedure was performed. During the follow-up, all patients' motion arc with elevation, abduction, lateral and medial rotation reached the same amplitude. Four (40\%) players were strikers, two (20\%) were full-backs, two (20\%) were defensive midfielders, one (10\%) was central-midfielder and one (10\%) was defender. The mean follow-up time was 1,251 days. There were no cases of glenohumeral arthrosis (Table 1). 


\begin{tabular}{c|c|c|c|c|c|c|c|c|c}
\multicolumn{2}{l}{ Table 1. Data of the professional athletes. } \\
\hline Sex & Age & Position & Follow-Up & Complications & Return to Sport & Failure & $\begin{array}{c}\text { Previous } \\
\text { Arthroscopy }\end{array}$ & $\begin{array}{c}\text { First } \\
\text { Dislocation-Surgery }\end{array}$ & $\begin{array}{c}\text { Dislocations } \\
\text { until Surgery }\end{array}$ \\
\hline M & 28 & Defensive Midfielder & 70 months & None & 3 months & None & No & 24 months & 10 \\
\hline M & 25 & Defender & 12 months & None & 2 months and 5 days & None & No & 1 month & 2 \\
\hline M & 24 & Defensive Midfielder & 10 months & None & 2 months and 10 days & None & No & 2 months & 2 \\
\hline M & 25 & Striker & 13 months & None & 2 months and 14 days & None & No & 6 months & 4 \\
\hline M & 16 & Striker & 3 months & None & 2 months & None & No & 4 months & 6 \\
\hline M & 26 & Central-Midfielder & 72 months & None & 3 months & None & Yes & 24 months & 3 \\
\hline M & 17 & Full-Back & 38 months & None & 3 months and 10 days & None & Yes & 8 months & 4 \\
\hline M & 27 & Striker & 58 months & None & 3 months and 28 days & None & No & 7 months & 4 \\
\hline M & 22 & Striker & 52 months & None & 4 months & None & No & 36 months & 6 \\
\hline M & 19 & Full-Back & 72 months & None & 4 months and 28 days & None & Yes & 12 months & 2 \\
\hline
\end{tabular}

\section{DISCUSSION}

The current literature shows that professional athletes present a high recurrence after arthroscopic treatment of anterior shoulder instability in contact sports. ${ }^{10}$ In our sample, 30\% of the patients underwent capsuloplasty, Bankart repair in another service and evolved with failure. Bacilla et al. ${ }^{11}$ found $10 \%$ of the new dislocations with only 18 months of follow-up; however, they were football athletes, and the arthroscopic procedures were performed by the author himself.

The values found for non-athletes cannot be compared with and analyzed for athletes. In initial studies on non-athletes, authors showed high numbers in the failure of arthroscopic Bankart repair, Flinkkila et al. ${ }^{10} 19 \%$, Voo et al. ${ }^{12} 18 \%$. However, after the advance of the arthroscopic procedure, some recent cases found similar and even lower values for failure rate. Milchteim et al. ${ }^{13}$ showed $6.4 \%$ in contact sports athletes with a return of $82.5 \%$ with the same performance level.

For an athlete, being away from sports practice in addition to reduced performance and prolonged recovery can cause devastating effects on their career. Hovelius et al. ${ }^{8}$ analyzed, in a comparative study (Lartajet versus Bankart repair), 185 shoulders in which Lartajet presented better postoperative stability and lower complication rates. An et al. ${ }^{9}$, in meta-analysis, described that Lartajet still has lower failure rates and better lateral rotation compared with the Bankart repair. ${ }^{9}$ Although the arthroscopic Bankart repair shows similar comparative values of reluxations in some case series, Lartajet still contains better clinical results and lower dislocation and subluxation rates after long-term follow-up, and it offers greater safety for athletes to resume their activities. ${ }^{4,3,13,14}$ For strikers, central-midfielders, defenders and full-backs, the instability can cause major problems for their careers. The residual pain, ROM loss and positive seizure are factors that can lead to fear of new dislocations due to falls and physical contact, reduced professional performance and inefficiency in throw-ins. Ekstrand et al. ${ }^{15}$ reported that shoulder dislocation represents the most serious upper limb injury in soccer, with an average leave time of 41 days. They have shown that the absence of training and games is twice higher for goalkeepers than for field players due to throw-ins, direct and indirect shoulder traumas for falls and defenses. The injuries in the upper limb in goalkeepers can reach frequent values up to $5 x$ more, compared with other soccer positions. ${ }^{1}$

Although this study is unique and the results differ from those of Cerciello et al. ${ }^{3}$ who studied 28 professional goalkeepers treated surgically and observed a $12.5 \%$ rate of recurrence, other analyses were verified with contact athletes, in which case series respect and match our low failure rate after the open Lartajet procedure. ${ }^{11,15}$ Privitera et al. ${ }^{5}$ described $8 \%$ and $14 \%$ of patients with postoperative instability perception (positive seizure), but without dislocation; however, from the cases analyzed, only six (8\%) were soccer players.

Neyton et al. in a 12-year follow-up after the surgical procedure in Rugby players did not find subluxation or anterior glenohumeral dislocation. ${ }^{16}$

In relation to the first dislocation, the mean time of surgery was 12.4 months. Each athlete had 4.3 shoulder dislocations until the procedure was performed. Cerciello et al. ${ }^{3}$ showed that the goalkeepers waited 2.2 dislocations, since they rely more on their shoulder than strikers, mid-fielders, defenders and full-backs present in our study and cannot wait to undergo surgery after the soccer season.

Positive seizure in the postoperative clinical evaluation was not obtained. Neyton et al. found $14 \%$ in rugby players through the Lartajet procedure. ${ }^{16}$

The mean time of return to sport was 93.5 days, with $100 \%$ return of players. Hart and Funk ${ }^{17}$ after the treatment of 25 soccer players by arthroscopic technique and five by Latarjet surgery returned to the fields after 81.9 days, on average, with no significant difference between goalkeepers and field players and without recurrences after 91 weeks of follow-up. Cerciello et al. ${ }^{3}$ reported excellent results for bone block (Latarjet) in a sample of 26 soccer players (28 shoulders). Only one player did not return to soccer. The mean return time was longer than in our study, 150 days. Eighteen players (20 shoulders, $71 \%$ of cases) returned to the same level. A goalkeeper suffered a recurrence 74 months after surgery. ${ }^{3}$

In comparison with other sports, we obtained a superior percentage of return to sports. Neyton et al. ${ }^{16}$ showed that Rugby players reached $67 \%$, Bonnevialle et al $^{16}, 97 \%$, and Larrain et al. ${ }^{18}$, $84 \%$. Privitera et al. ${ }^{5}$ obtained $72 \%$ return to activities, $63 \%$ at the same previous competitive level; however, the sample of the study consisted of higher-risk sports (football, hockey, skiing, snowboarding, martial arts, wrestling, boxing).

It is of paramount importance to highlight the success of the Lartajet procedure in high-performance athletes, not only due to early functional improvement, lower chance of postoperative seizure, but because they are submitted to early return to professional activities, small rest time between games, intense physical contact, need to return early to high performance level and due to lower rates of recurrence.

This study has some limitations, because it is a retrospective analysis, a unique surgical technique. Only 10 patients were studied, but it is noteworthy that they are professional athletes with long follow-up time. 


\section{CONCLUSION}

This study showed that the Latarjet procedure in the treatment of recurrent anterior instability in professional soccer players is effective. The Latarjet procedure allowed all professional athletes to return to sports quickly, without dislocations and subluxation, negative seizure and no complications during the follow-up.

AUTHORS' CONTRIBUTIONS: Each author contributed individually and significantly to the development of this article. GAS: authorship, writing, review, intellectual concept of the article and preparation of the entire research project. EBSL: authorship, writing, review and intellectual concept of the article; DHC: authorship, writing, review and intellectual concept of the article; PSB: authorship and review of the articlel; CVA: authorship, writing, review and intellectual concept of the article; BE: authorship, writing, review and intellectual concept of the article.

\section{REFERENCES}

1. Marom N, Williams RJ 3rd. Upper extremity injuries in soccer. Am J Orthop (Belle Mead NJ). 2018;47(10):1-10.

2. Ekstrand J, Hägglund $M$, Waldén $M$. Injury incidence and injury patterns in professional football: The UEFA injury study. Br J Sports Med, 2011:45(7):553-8.

3. Cerciello S, Edwards T B, Walch G. Chronic anterior glenohumeral instability in soccer players: results for a series of 28 shoulders treated with the Latarjet procedure. J Orthop Traumatol, 2012;13(4):197-202.

4. Beranger JS, Klouche S, Bauer T, Demoures T, Hardy P. Anterior shoulder stabilization by Bristow-Latarjet procedure in athletes: return-to-sport and functional outcomes at minimum 2-year follow-up. Eur J Orthop Surg Traumatol. 2016;26(3):277-82.

5. Privitera DM, Sinz N, Miller L, Siegel E, Solberg M, Daniels S, Higgins L. Clinical outcomes following the Latarjet procedure in contact and collision athletes. J Bone Joint Surg Am. 2018;100(6):459-65.

6. Balg F, Boileau P. The instability severity index score: a simple pre-operative score to select patients for arthroscopic or open shoulder stabilisation. J Bone Joint Surg Br. 2007 ;89(11):14707.

7. Pillai G, Baynes JR, Gladstone J, Flatow EL. Greater strength increase with cyst decompression and SLAP repair than SLAP repair alone. Clin Orthop Relat Res. 2011;469(4):1056-60.

8. Hovelius L, Vikerfors O, Olofsson A, Svensson O, Rahme H. Bristow-Latarjet and Bankart: a comparative study of shoulder stabilization in 185 shoulders during a seventeen-year follow-up. J Shoulder Elbow Surg, 2011;20(7):1095-101.

9. An VVG, Sivakumar BS, Phan K, Trantalis J. A systematic review and meta-analysis of clinical and patient-reported outcomes following two procedures for recurrent traumatic anterior instability of the shoulder: Latarjet procedure vs. Bankart repair. J Shoulder Elbow Surg, 2016:25(5):853-63.
10. Flinkkilä T, Hyvönen $P$, Ohtonen $P$, Leppilahti J. Arthroscopic Bankart repair: Results and risk factors of recurrence of instability. Knee Surg Sports Traumatol Arthrosc, 2013;18(12):1752-8

11. Bacilla P, Field LD, Savoie FH III. Arthroscopic bankart repair in a high demand patient population, 2009;13(1):202-7.

12. Voos JE, Livermore RW, Feeley BT, Altchek DW, Williams RJ, Warren RF, et al. Prospective evaluation of arthroscopic bankart repairs for anterior instability. Am J Sports Med. 2010;38(2):302-7.

13. Milchteim C, Tucker SA, Nye DD, Lamour RJ, Liu W, Andrews JR, Ostrander RV. Outcomes of bankart repairs using modern arthroscopic technique in an athletic population. Arthroscopy. 2016;32(7):1263-70.

14. Grana WA, Buckley PD, Yates CK. Arthroscopic Bankart suture repair. Am J Sports Med. 1993;21(3):348-53.

15. Ekstrand J, Hägglund M, Törnqvist H, Kristenson K, Bengtsson H, Magnusson $\mathrm{H}$, Waldén M. Upper extremity injuries in male elite football players. Knee Surg Sports Traumatol Arthrosc, 2013;21(7):1626-32.

16. Neyton L, Young A, Dawidziak B, Visona E, Hager JP, Fournier Y, Walch G. Surgical treatment of anterior instability in rugby union players: clinical and radiographic results of the Latarjet-Patte procedure with minimum 5-year follow-up. J Shoulder Elbow Surg, 2012;21(12):1721-7.

17. Hart D, Funk L. Serious shoulder injuries in professional soccer: return to participation after surgery. Knee Surg Sports Traumatol Arthrosc, 2015;23(7):2123-9.

18. Larrain MV, Montenegro HJ, Mauas DM, Collazo CC, Pavón F. Arthroscopic management of traumatic anterior shoulder instability in collision athletes: analysis of 204 cases with a 4- to 9-year follow-up and results with the suture anchor technique. Arthroscopy. 2006;22(12):1283-9. 